\title{
Compositional variations of the pyroxenes from three flows of Faeroe Islands basalts
}

\author{
AAGE JENSEN
}

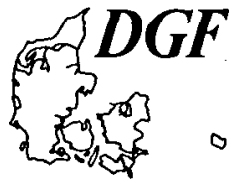

Jensen, Aa.: Compositional variations of the pyroxenes from three flows of Faeroe Islands basalts. Bull. geol. Soc. Denmark, vol. 27, Special Issue, pp. 63-78, Copenhagen, July 30th, 1978. https://doi.org/10.37570/bgsd-1978-SI-08

The pyroxenes from one flow from the lower lava series, one from the middle, and one from the upper lava series of the Faeroe Islands have been investigated by microprobe.

The flow from the lower series has augite as the only pyroxene, the flow from the middle series has bronzite as phenocrysts and augite and pigeonite, and the flow from the upper series has augite and pigeonite. 30 analyses of these pyroxenes are presented, comprising eight elements: $\mathrm{Si}, \mathrm{Ti}, \mathrm{Al}, \mathrm{Fe}, \mathrm{Mn}, \mathbf{M g}$, $\mathrm{Ca}$ and $\mathrm{Na}$, and the formulae based on four cations are calculated. Variations in major elements are shown in figs. 2-8; in these diagrams are also used the results of 116 partial analyses, comprising only $\mathrm{Mg}, \mathrm{Fe}$ and $\mathrm{Ca}$. The variations in minor elements and their distribution between augites and Ca-poor pyroxenes are discussed.

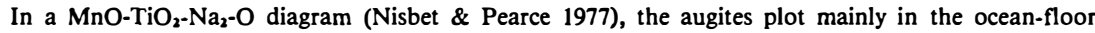
basalt field, but a number of analyses fall in the field common to all the basalt types. $F_{1}-F_{2}$ values (Nisbet \& Pearce 1977) correspond partly to the field where ocean-floor basalts and within-plate tholeiites overlap, and partly to the field where ocean-floor and volcanic arc basalts overlap.

Aage Jensen, Institute of Mineralogy, University of Copenhagen, Oster Voldgade 5-7, DK-1350 Copenhagen $K$, Denmark. January 16 th, 1978.

The Faeroe Islands consist exclusively of floodbasalt lavas poured out subaerally in the earliest Tertiary and forming a pile $3000 \mathrm{~m}$ thick (Noe-Nygaard \& Rasmussen 1968, Rasmussen \& Noe-Nygaard 1969). This pile is divided into three series: the lower series, the middle series and the upper series (Noe-Nygaard 1962). The lower series comprises $900 \mathrm{~m}$ of mainly aphyric basalts and is separated from the middle series by a $15 \mathrm{~m}$ thick sedimentary coal-bearing series. The average thickness of single lava flows in the lower series is about $20 \mathrm{~m}$, whereas the single flows of the middle series, which comprises $1350 \mathrm{~m}$ of mainly porphyritic basalts, are considerably thinner, having thicknesses down to $10 \mathrm{~cm}$. The upper series comprises $675 \mathrm{~m}$ of mainly olivine-bearing basalts, the single flows being about $10 \mathrm{~m}$ in thickness.

The pyroxenes from one flow from each of these three lava series have been investigated by microprobe analyses.

The flow investigated from the lower series is the second uppermost flow. The sampling was carried out on Syderi at the road tunnel between Tvera and Kvalbø, where the second uppermost flow is probably $17 \mathrm{~m}$ thick, of which $131 / 2 \mathrm{~m}$ are accessible. Two samples were investigated: 63016 taken about $2 \mathrm{~m}$ above the lower contact of the flow, and 63023 taken about $9 \mathrm{~m}$ above the lower contact.

The flow from the middle series was sampled on Bordø in the quarry at Klaksvig, where an $11 \mathrm{~m}$ thick flow is exposed in full thickness, a thickness which is unusually large for a flow from the middle series. The samples investigated, 63135 and 63141 , were collected $25 \mathrm{~cm}$ and $5 \mathrm{~m}$ respectively above the lower contact of the flow.

The samples from the upper series were collected from the flow ocurring along the quay of Torshavn, Strømø. This flow is an $181 / 2 \mathrm{~m}$ thick plagioclase-porphyritic basalt. The samples investigated, 63171,63176 and 63182 , were taken immediately above the lower contact, $4 \mathrm{~m}$ above and $9 \mathrm{~m}$ above the lower contact respectively.

\section{Sample description}

63016. Fine-grained grey basalt with intersertal texture. Augite is the only pyroxene present. The larger grains of plagioclase and augite are occa- 
sionally clustered into glomeroporhyritic aggregates with a diameter about $1 \mathrm{~mm}$. The analysed grains of augite vary in size from $30 \times 40 \mu \mathrm{m}$ to $330 \times 600 \mu \mathrm{m}$. The Fe-Ti-oxides mainly have oxidation indices (Watkins \& Haggerty 1967) 2 and 3, but some grains have reached 4 .

63023. Fine-grained grey basalt with intersertal to intergranular texture. Augite is the only pyroxene present. The larger grains of plagioclase and augite are occasionally clustered intoglomeroporphyritic agregates with diameter about $1 \mathrm{~mm}$. The analysed grains of augite vary in size from $30 \times 30 \mu \mathrm{m}$ to $300 \times 450 \mu \mathrm{m}$. The Fe-Ti-oxides represent all stages of oxidation from index 2 to index 6.

63135. Fine-grained grey basalt with phenocrysts of orthopyroxene up to $2 \mathrm{~mm}$, they are to some extent clustered in glomeroporphyritic aggregates up to $4 \mathrm{~mm}$. The texture is intergranular to intersertal. The groundmass pyroxenes comprise pigeonite as well as augite. The analysed grains of augite vary in size from $15 \times 20 \mu \mathrm{m}$ to $40 \times 90 \mu \mathrm{m}$. The analysed grains of pigeonite vary from $20 \times 20 \mu \mathrm{m}$ to $30 \times 90 \mu \mathrm{m}$. The Fe-Ti-oxides have oxidation indices 1 and 2 .

63141. Fine-grained grey basalt with phenocrysts of orthopyroxene up to $1 \mathrm{~mm}$, they are occasionally clustered in glomeroporphyritic aggregates up to $2 \mathrm{~mm}$. The texture is intergranular to intersertal. The groundmass pyroxenes comprise pigeonite as well as augite. The grain size of the groundmass is slightly larger than in 63135 . The analysed grains of augite vary in size from $30 \times 45$ $\mu \mathrm{m}$ to $35 \times 140 \mu \mathrm{m}$. The analysed grains of pigeonite vary from $30 \times 60 \mu \mathrm{m}$ to $60 \times 75 \mu \mathrm{m}$. The Fe-Ti-oxides have oxidation indices 1 and 2.

63171. Redbrown plagioclase-porphyritic basalt with fine-grained groundmass, the texture of which is intergranular to intersertal. The plagioclase phenocrysts are to a large extent clustered into glomeroporphyritic aggregates up to $5 \mathrm{~mm}$ in diameter. The basalt is somewhat vesicular with rounded vesicles, the diameter of which can reach $5 \mathrm{~mm}$. Augite is the only pyroxene present, and the analysed grains vary in size from $90 \times 120 \mu \mathrm{m}$ to $450 \times 450 \mu \mathrm{m}$. The Fe-Ti-oxides all have oxidation index 6.

63176. Grey plagioclase-porphyritic basalt with fine-grained groundmass, the texture of which is intergranular to intersertal. The plagioclase phenocrysts are to a large extent clustered into glomero- porphyritic aggregates up to $5 \mathrm{~mm}$ in diameter. The grain size of the groundmass is less than in 63171 . The pyroxene is mainly augite, but pigeonite is present in sparse amount. One grain of pigeonite, $30 \times 60 \mu \mathrm{m}$ in size, was analysed. The analysed grains of augite vary in size from $30 \times 45 \mu \mathrm{m}$ to $300 \times 390 \mu \mathrm{m}$. The Fe-Ti-oxides mainly have oxidation index 3 , but some grains have index 4 .

63182. Grey plagioclase-porphyritic basalt with fine-grained groundmass, the texture of which is intergranular to intersertal. The plagioclase phenocrysts are to a large extent clustered into glomeroporphyritic aggregates up to $5 \mathrm{~mm}$ in diameter. The grain size of the groundmass is intermediate between 63171 and 63176 . The pyroxenes comprise pigeonite as well as augite. Pigeonite is much more frequent than in 63176 and occurs often as rather large grains. The analysed grains of augite vary in size from $30 \times 45 \mu \mathrm{m}$ to $150 \times 200$ $\mu \mathrm{m}$, and analysed grains of pigeonite from $30 \times 45$ $\mu \mathrm{m}$ to $225 \times 600 \mu \mathrm{m}$. The Fe-Ti-oxides mainly have oxidation index 3 , but some grains have index 4 .

\section{Rock analyses}

The rock samples have been analysed in the laboratory of the Geological Survey of Greenland by Ib Sørensen. $\mathrm{H}_{2} \mathrm{O}^{+}$was determited by the Penfield method and $\mathrm{Fe}^{++}$by wet chemistry. $\mathrm{Mg}$ was determined by complexometric titration, $\mathrm{Na}$ by flame photometry, and the remaining elements were analysed with XRF on glass discs. The results of the analyses are given in table 1 together with the calculated C.I.P.W. weight norms. The norms are calculated with the ratio $\mathrm{Fe}_{2} \mathrm{O}_{3} / \mathrm{Fe} 0$ as found by analyses (first column) as well as with this ratio adjusted to 0.15 (second column).

With the ratio $\mathrm{Fe}_{2} \mathrm{O}_{3} / \mathrm{Fe} 0$ as found by analyses the samples are all quartz tholeiites (Yoder \& Tilley 1962). But whereas the samples from the lower and middle series remain quartz tholeiites also with the adjusted ratio, the use of this ratio turns two of the samples from the upper series into olivine tholeiites, while a small amount of normative quartz remains in the third.

Compared to the average quartz basalt by Manson (1967) the samples from the lower series are low in $\mathrm{Si}, \mathrm{Al}$ and $\mathrm{K}$, and high in $\mathrm{Ti}, \mathrm{Fe}, \mathrm{Mn}, \mathrm{Ca}$ and $\mathrm{P}$, and they have a somewhat higher ratio of $\mathrm{Fe}_{2} \mathrm{O}_{3} / \mathrm{Fe} 0$ than the average quartz basalt. 


\begin{tabular}{|c|c|c|c|c|c|c|c|c|c|c|c|c|c|c|c|c|}
\hline \multirow[b]{2}{*}{ Sample } & \multirow{2}{*}{\multicolumn{2}{|c|}{ number }} & \multicolumn{4}{|c|}{$\begin{array}{l}\text { Table } 1 . \text { Chem } \\
\text { Lower series }\end{array}$} & \multicolumn{6}{|c|}{ nical analyses of rock samples } & \multicolumn{4}{|c|}{ Upper series } \\
\hline & & & \multicolumn{2}{|c|}{63016} & \multicolumn{2}{|c|}{63023} & \multicolumn{2}{|c|}{63135} & \multicolumn{2}{|c|}{63141} & \multicolumn{2}{|c|}{63171} & \multicolumn{2}{|c|}{63176} & \multicolumn{2}{|c|}{63182} \\
\hline \multirow{13}{*}{ (1) } & \multicolumn{2}{|c|}{$\mathrm{SiO}_{2}$} & \multicolumn{2}{|c|}{48.14} & \multicolumn{2}{|c|}{48.09} & \multicolumn{2}{|c|}{53.94} & \multicolumn{2}{|c|}{53.68} & \multicolumn{2}{|c|}{48.06} & \multicolumn{2}{|c|}{49.54} & 49. & .33 \\
\hline & \multicolumn{2}{|c|}{$\mathrm{TiO}_{2}$} & \multicolumn{2}{|c|}{3.30} & \multicolumn{2}{|c|}{3.20} & & .45 & & .49 & & .64 & & .97 & & .66 \\
\hline & $\mathrm{Al}_{2} \mathrm{C}$ & & 13 . & 48 & 13. & .20 & 12 & .85 & 12 & .78 & 14. & .92 & 13. & .80 & 14. & .26 \\
\hline & $\mathrm{Fe}_{2} \mathrm{O}$ & & & .66 & & .79 & & .99 & & .38 & 10. & .05 & & .83 & & .88 \\
\hline & $\mathrm{FeO}$ & & & .90 & & .64 & & .70 & & .48 & & .97 & & .74 & & .94 \\
\hline & Mno & & & .22 & & .21 & & .08 & & .01 & & .16 & & .22 & & .29 \\
\hline & $\mathrm{MgO}$ & & & .63 & & .70 & & .83 & & .96 & & .88 & & .91 & & .16 \\
\hline & $\mathrm{CaO}$ & & 10. & .48 & 10. & .58 & & .60 & & .76 & 10. & .84 & 10. & .47 & 10. & .60 \\
\hline & $\mathrm{Na}_{2} \mathrm{O}$ & & & .54 & & .49 & & .35 & & .43 & & .73 & & .69 & & .92 \\
\hline & $\mathrm{K}_{2} \mathrm{O}$ & & & .23 & & .30 & & .93 & & .69 & & .26 & & .41 & & .40 \\
\hline & $\mathrm{H}_{2} \mathrm{O}$ & & & .95 & & .96 & & .90 & & .78 & & .57 & & .64 & & .84 \\
\hline & $\mathrm{P}_{2} \mathrm{O}_{5}$ & & & 38 & & .37 & & 14 & & .13 & & .20 & & .23 & & .23 \\
\hline & Sum & & 99. & 91 & 99. & .53 & 99. & .76 & 99. & .57 & 100. & .28 & 100. & .45 & 100 & .51 \\
\hline C.I.P.V & W. we & eight & norms & & & & & & 。 & & & & & & & \\
\hline & $\mathbf{Q}$ & & 5.05 & 0.75 & 5.16 & 0.69 & 5.16 & 4.33 & 4.15 & 4.04 & 5.11 & & 3.91 & 0.41 & 1.02 & \\
\hline & or & & 1.36 & 1.36 & 1.77 & 1.77 & 5.50 & 5.50 & 4.08 & 4.08 & 1.54 & $1: 54$ & 2.42 & 2.42 & 2.36 & 2.36 \\
\hline & $a b$ & & 21.49 & 21.49 & 21.07 & 21.07 & 19.89 & 19.89 & 20.56 & 20.56 & 23.10 & 23.10 & 22.76 & 22.76 & 24.71 & 24.71 \\
\hline & an & & 24.70 & 24.70 & 23.96 & 23.96 & 21.77 & 21.77 & 21.93 & 21.93 & 27.69 & 27.69 & 24.37 & 24.37 & 24.62 & 24.62 \\
\hline & wo $\mid$ & & 10.36 & 10.36 & 10.90 & 10.91 & 8.35 & g. 34 & 8.63 & 8.63 & 10.35 & 10.35 & 10.89 & 10.89 & 11.05 & 11.05 \\
\hline & en & $d i$ & 6.59 & 4.78 & 7.08 & 5.07 & 5.32 & 5.09 & 5.30 & 5.27 & 8.94 & 5.17 & 6.76 & 5.26 & 6.52 & 5.49 \\
\hline & $f s$ & & 3.11 & 5.48 & 3.09 & 5.72 & 2.48 & 2.79 & 2.85 & 2.89 & 0.00 & 4.96 & 3.48 & 5.45 & 3.98 & 5.34 \\
\hline & en & hy & 7.44 & 9.24 & 7.12 & 9.12 & 16.66 & 16.90 & 17.02 & 17.04 & 5.70 & 6.97 & 7.95 & 9.46 & 8.82 & 6.96 \\
\hline & fs & & 3.51 & 10.59 & 3.10 & 10.28 & 7.77 & $9.2 B$ & 9.14 & 9.34 & 0.00 & 6.70 & 4.09 & 9.79 & 5.38 & 6.75 \\
\hline & fo & 01 & & & & & & & & & & 1.75 & & & & 2.03 \\
\hline & fal & & & & & & & & & & & 1.86 & & & & 2.17 \\
\hline & hm & & & & & & & & & & 8.37 & & & & & \\
\hline & $m t$ & & 8.21 & 2.68 & 8.39 & 2.65 & 2.89 & 1.82 & 2.00 & 1.86 & 2.44 & 2.30 & 7.00 & 2.51 & 5.63 & 2.38 \\
\hline & i 1 & & 6.27 & 6.27 & 6.08 & 6.08 & 2.75 & 2.75 & 2.83 & 2.83 & 5.01 & 5.01 & 5.64 & 5.64 & 5.05 & 5.05 \\
\hline & ap & & 0.88 & 0.88 & 0.86 & 0.86 & 0.32 & 0.32 & 0.30 & 0.30 & 0.46 & 0.46 & 0.53 & 0.53 & 0.53 & 0.53 \\
\hline
\end{tabular}

The samples from the middle series have an unusual composition as $\mathrm{Mg} 0$ is higher than $\mathrm{CaO}$. Compared to the average quartz basalt the samples are low in $\mathrm{Al}, \mathrm{Mn}, \mathrm{Ca}$ and $\mathrm{P}$, and high in $\mathrm{Si}$ and $\mathrm{Mg}$. The ratio of $\mathrm{Fe}_{2} \mathrm{O}_{3} / \mathrm{FeO}$ is considerably lower for the samples than for the average quartz basalt.

Concerning the samples from the upper series, 63171 (in which the Fe-Ti-oxides all have oxidation index 6) is so rich in $\mathrm{Fe}_{2} \mathrm{O}_{3}$ that it cannot pass the screen for rocks of basaltic composition by Manson (1967). 63182 has the same ratio of $\mathrm{Fe}_{2} \mathrm{O}_{3} /$ $\mathrm{Fe} 0$ as the average quartz basalt, whereas 63176 has a somewhat higher ratio. Compared to the average olivine tholeiite of Manson (1967) the samples from the upper series all have high values of the ratio $\mathrm{Fe}_{2} \mathrm{O}_{3} / \mathrm{Fe} 0$.

In relation to the average quartz basalt as well as the average olivine tholeiite the samples are low in $\mathrm{Al}$ and $\mathrm{K}$, and high in $\mathrm{Ti}, \mathrm{Fe},(\mathrm{Mn}), \mathrm{Ca}$ and $\mathrm{Na}$, whereas $\mathrm{Si}$ and $\mathrm{Mg}$ for the samples are intermediate between the values of the two average basalts.

It can be noted that in all three flows the contents of $\mathrm{Mg}$ is higher in the interior of the flow than at the contact. In the upper series also $\mathrm{Na}$ and $\mathrm{K}$ are higher in the interior of the flow, whereas in the middle series $\mathrm{K}$ is highest at the contact.

Noe-Nygaard (1966) pointed out that the Faeroes-Iceland-Greenland basalts differ from the mid-ocean ridge basalts in that they are higher in $\mathrm{Fe}, \mathrm{Ti}$ and $\mathrm{P}$, and lower in $\mathrm{Al}$ and $\mathrm{Mg}$. Brooks \& Jakobsson (1974) introduced the designation FETI for the Fe-Ti-rich type. On the basis of rare-earth evidence, Schilling \& Noe-Nygaard (1974) suggested that the Fe-Ti-rich basalts of the lower and middle series were plume-derived, whereas the upper series is more akin to normal mid-ocean ridge basalts. This idea was further elaborated by Bol- 
lingberg, Brooks \& Noe-Nygaard (1975) who suggest that the lower series was erupted under vigorous plume activity, the middle series erupted during the waning phase of plume activity, and the upper series erupted by typical ocean tholeiite magmas without influence from plume activity.

The two samples from the lower series, 63016 and 63023 , correspond well with the average of the lower series (Rasmussen \& Noe-Nygaard 1969, Bollingberg, Brooks \& Noe-Nygaard 1975) and could be classified as FETI-basalts characteristic of plume activity.

The flows from the middle and upper series investigated here, however, cannot be taken as representative for their respective series, and the samples deviate beyond the standard deviation for the average composition of the series given by Bollingberg, Brooks \& Noe-Nygaard (1975).

Although they have a deviating composition the samples from the middle and upper series may support the idea of Schilling \& Noe-Nygaard (1974), as they reflect a development away from the plume-derived FETI-basalts of the lower series towards more normal mid-ocean ridge basalts.

Thus in the flow from the middle series the ele- ments $\mathrm{Ti}, \mathrm{Fe}, \mathrm{Mn}$ and $\mathrm{Mg}$ are present in amounts corresponding to mid-ocean ridge basalts, whereas the remaining elements (except $P$, see below) still show FETI-characteristics.

In the flow from the upper series such a division of elements cannot be made, but the composition is in many respects intermediate between midocean ridge basalt and FETI-basalt, and the samples certainly are less FETI than the samples from the lower series.

The comparisons between basalt types by Bollingberg, Brooks \& Noe-Nygaard (1975) are based on analyses recalculated to $100 \% \mathrm{H}_{2} \mathrm{O}-\mathrm{P}_{2} \mathrm{O}_{5}$-free, but Noe-Nygaard (1966) found Faeroe Islands basalts to be richer in $\mathrm{P}$ than mid-ocean ridge basalts, and it is clearly seen that the samples from the upper series and specially the samples from the middle series are lower in $\mathrm{P}$ than the samples from the lower series.

Pearce, Gorman \& Birkett (1975) used $\mathrm{TiO}_{2}, \mathrm{~K}_{2} \mathrm{O}$ and $\mathrm{P}_{2} \mathrm{O}_{5}$ to discriminate between oceanic and nonoceanic basalts. Plotted in the $\mathrm{TiO}_{2}=\mathrm{K}_{2} \mathrm{O}-\mathrm{P}_{2} \mathrm{O}_{5}$ diagram (fig. 1) the samples from the lower and upper series fall well within the oceanic field, trending towards the non-oceanic field from contact to-

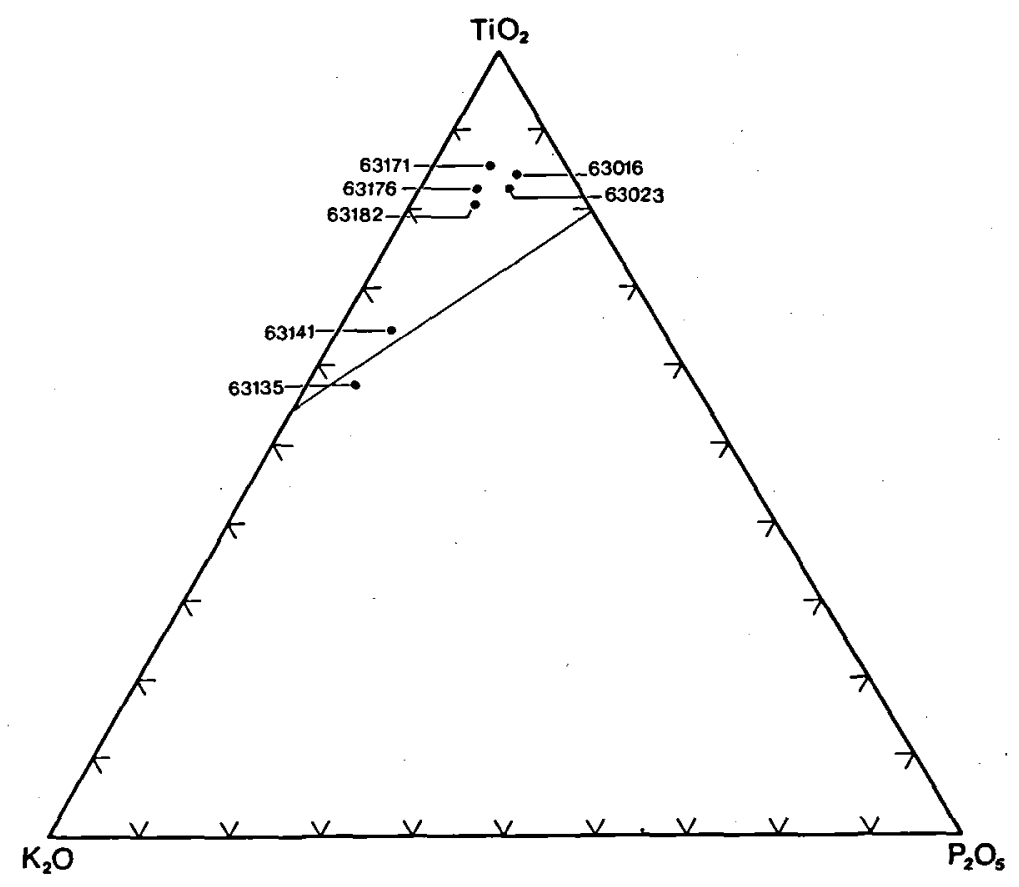

Fig. 1. $\mathrm{TiO}_{2}-\mathrm{K}_{2} \mathrm{O}-\mathrm{P}_{2} \mathrm{O}_{3}$ diagram (Pearce, Gorman \& Birkett 1975). Oceanic field above and non-oceanic field below dividing line. 
wards interior of flow. The samples from the middle series fall on either side of the dividing line between oceanic and non-oceanic basalts with the contact sample on the non-oceanic side.

Values of the discriminant functions of Pearce (1976) are given in table 2. In an $F_{1}-F_{2}$ diagram the lower and upper series both plot in the within-plate basalt field, the upper series lying closer to the ocean-floor basalt field than the lower series. The middle series plot in the field of volcanic arc basalts, the sample from the flow interior lying closer to the field of ocean-floor basalts than the contact sample. In an $F_{2}-F_{3}$ diagram the middle series plot in the field of low-potassium tholeiites, but the sample from the flow interior is very close to the border of the field of ocean-floor basalts.

Table 2. Values of discriminant functions calculated after Pearce (1976)

\begin{tabular}{lllll}
\multicolumn{2}{c}{ Sample number } & $\mathbf{F}_{\mathbf{1}}$ & $\mathbf{F}_{\mathbf{2}}$ & $\mathbf{F}_{\mathbf{3}}$ \\
\hline \multirow{2}{*}{ Lower series } & 63016 & 0.199 & -1.537 & \\
& 63023 & 0.202 & -1.525 & \\
\multirow{2}{*}{ Middle series } & 63135 & 0.381 & -1.508 & -2.397 \\
& 63141 & 0.373 & -1.536 & -2.397 \\
\hline \multirow{3}{*}{ Upper series } & 63171 & 0.243 & -1.537 & \\
& 63176 & 0.232 & -1.543 & \\
& 63182 & 0.248 & -1.554 & \\
\hline
\end{tabular}

63016 and 63023 have indicator ratios (Coombs 1963) 0.34 and 0.32 respectively. 63171 and 63182 both have the indicator ratio 0.28 , and 63176 has 0.32 . This means that the flows from the lower and upper series have indicator ratios in the range where hypersthene appears to be unknown and pigeonite rare or absent. Hypersthene is not found in either flow, and the flow from the lower series is also without pigeonite, whereas pigeonite in the flow from the upper series is only absent in the contact sample 63171 , occurs sparse in 63176 , and is abundant in 63182 .

The flow from the middle series have indicator ratios $0.52(63135)$ and 0.51 (63141). The values thus are just above the limiting value of 0.50 , below which hypersthene is seldom found.

\section{Pyroxene analyses}

The pyroxenes were analysed with a HitachiXMA$5 B$ electron microprobe using $15.0 \mathrm{kV}$ accelerating voltage and a sample current on a Faraday cage of $20.0 \mathrm{nA}$. Stoichiometric oxides and silicates were used as standards. The correction programme used, EMSKOR, is based on the programme made by Springer (1967), but modified by Rønsbo, Institute of Mineralogy, University of Copenhagen, in accordance with the suggestions of Sweatman \& Long (1969). Total iron has been divided between ferrous and ferric iron by the method suggested by Finger (1972). The distribution of elements between Z- and M-positions is in accordance with the method outlined by Hess (1949).

In this paper are presented 30 pyroxene analyses comprising the elements $\mathrm{Si}, \mathrm{Ti}, \mathrm{Al}, \mathrm{Fe}, \mathrm{Mn}, \mathrm{Mg}$, $\mathrm{Ca}$ and $\mathrm{Na}$. Furthermore the results of 116 partial analyses, comprising only $\mathrm{Fe}, \mathrm{Mg}$ and $\mathrm{Ca}$, are used in some of the plots, but are not given in tables. For these partial analyses an amount of $\mathrm{Mn}$, obtained by interpolation from the two nearest analyses with determination of $\mathrm{Mn}$, was allotted to $\mathrm{Fe}$ in the calculation of atomic percentages of $\mathrm{Ca}, \mathrm{Mg}$ and $\mathrm{Fe}$, and the Fe-values in these calculations comprise total iron and manganese.

Table 3 gives the results of 19 analyses of augite, and table 4 gives the Ca-poor pyroxenes: 8 bronzites and 3 pigeonites.

\section{Variations in major elements}

The augites from the contact sample of the flow from the upper series are plotted in fig. 2 . If the three ringed plots, which represent the rim part of relatively large grains, are left out of consideration, the augites here seem to represent a quench trend comparable to the findings of Smith \& Lindsley (1971) for a flow from the Columbia River basalt.

The three ringed plots would fit better in fig. 3 where the augites from the interior of the flow are plotted. The augites here show a normal trend with a position intermediate between the Skaergaard trend (Brown 1957) and the Thingmulitrend (Carmichael 1967). This is in contrast to the flow of Columbia River basalt where Smith \& Lindsley (1971) found the normal trend from the interior of the flow to be more calcic than the Skaergaard trend. The reason for the lower $\mathrm{Ca}$ contents in the augites from the Faroe Islands flow might be that this flow is plagioclase-porphyritic, and the plagio- 


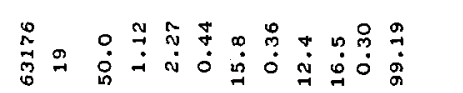

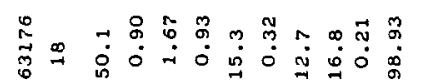

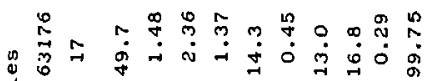

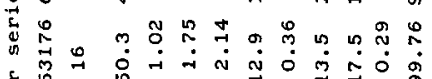

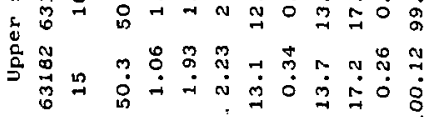

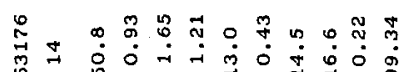

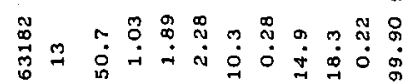

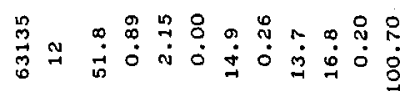

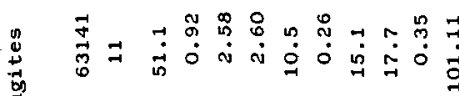

ฮั

崩

m

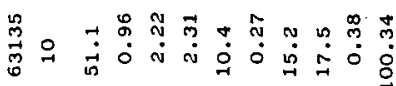

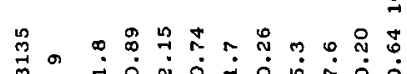

-

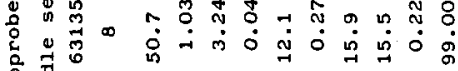

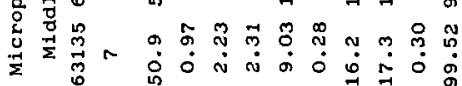

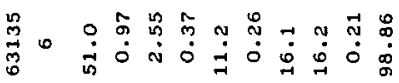

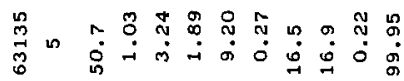

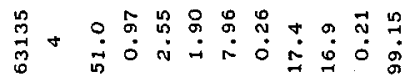

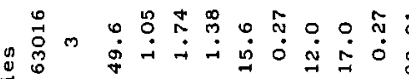

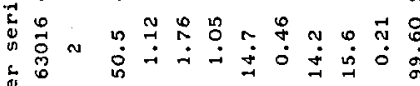

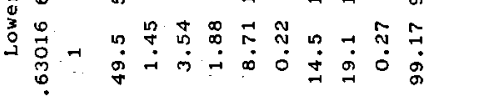

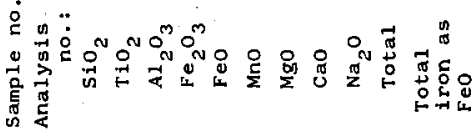

3
7
0
0
0
0

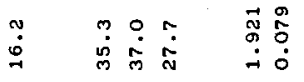

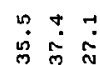

)

:

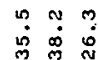

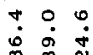

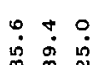

西

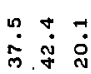

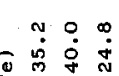

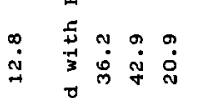

(4) 离 牙

$\stackrel{+}{\sim}$

$\vec{n}$

$\ddot{z}$

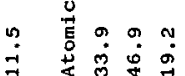

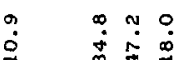

के

ำ

की

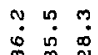

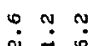

27

草

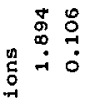

殸骂器

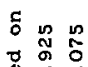

웜

1.

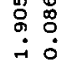

กั้

葛

ㅇํㄹำำ

วิㅇํㅇํำ

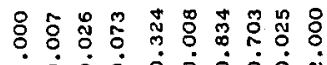

نं

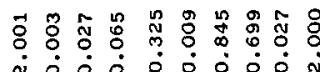

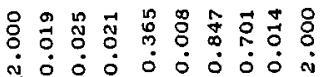

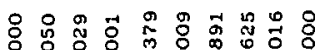

إن

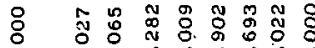

ن

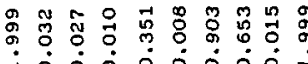

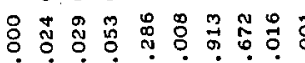

نं

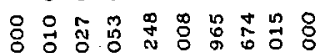

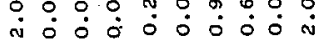

路

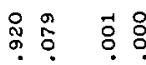

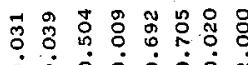

$\rightarrow 0$

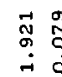

要

ดั

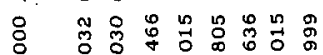

व करों कों क्ष

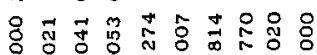

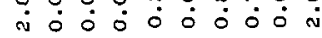

ฤะฤ:
$+$ 秦: 


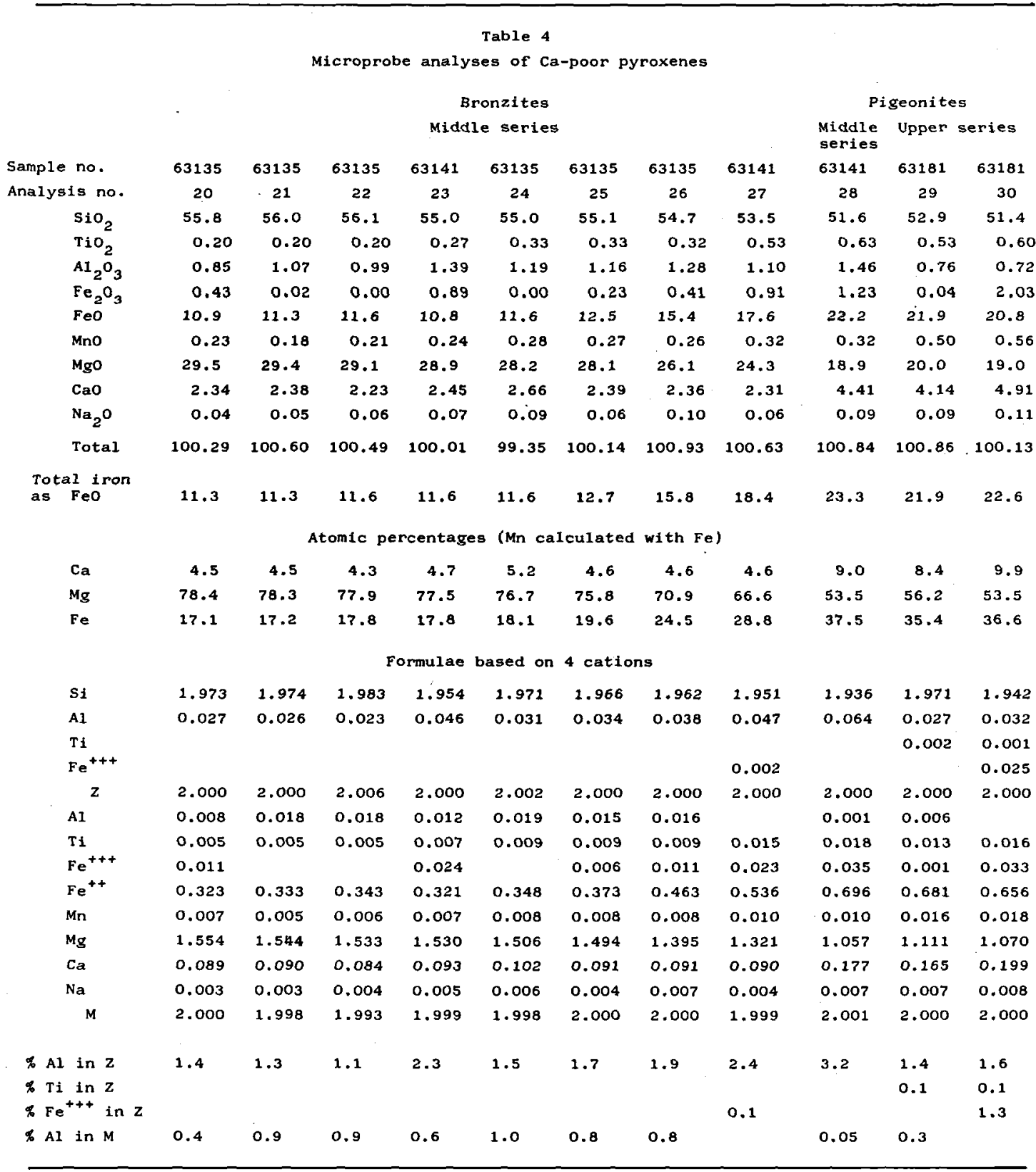

clase phenocrysts could have depleted the magma in $\mathrm{Ca}$ relative to $\mathrm{Mg}$ and $\mathrm{Fe}$.

Considering the augites from the flow from the lower series, the values obtained for the interior of the flow (fig. 5) conform to the Skaergaard trend, whereas the values from the outer part of the flow (fig. 4) show a rather scattered picture. In the interpretation it must be remembered that the sample from the outer part of this flow is about $2 \mathrm{~m}$ above the contact, and thus a quench trend cannot be expected to show as clearly as in samples closer to the contact. The ringed values are all from the central part of rather large grains, and it is believed that the trend shown by these values represent a quench trend.

Concerning the values of the augites from the 


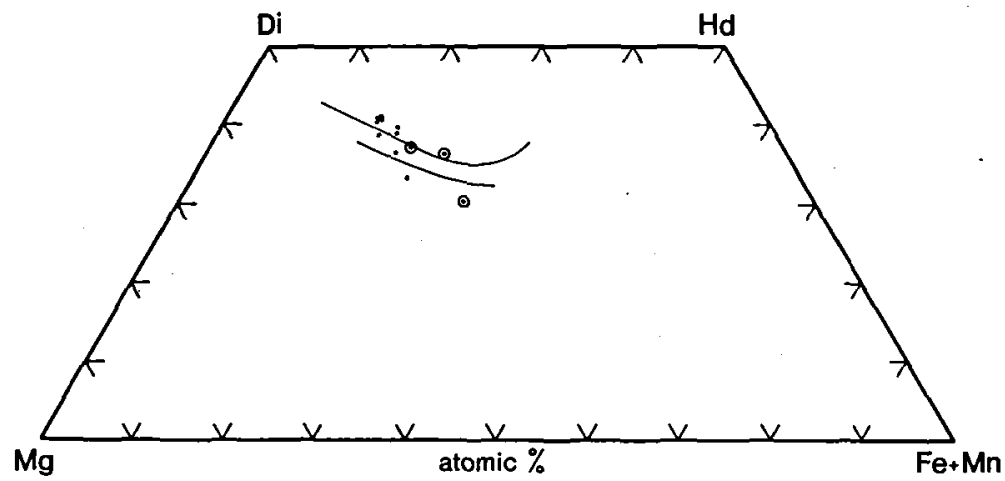

Fig. 2. Augites from the contact sample (63171) of the flow from the upper series. Ringed values represent analyses of rim of large grains. Upper line is the Skaergaard trend (Brown 1957), lower line is the Thingmuli trend (Carmichael 1967).

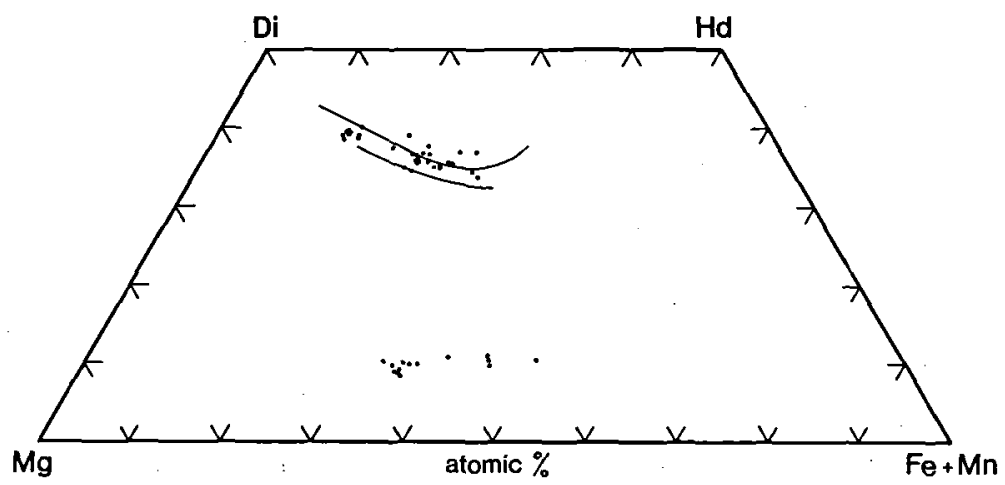

Fig. 3. Augites and pigeonites from the interior of the flow from the upper series (63176 \& 63182). Lines as in fig. 2.

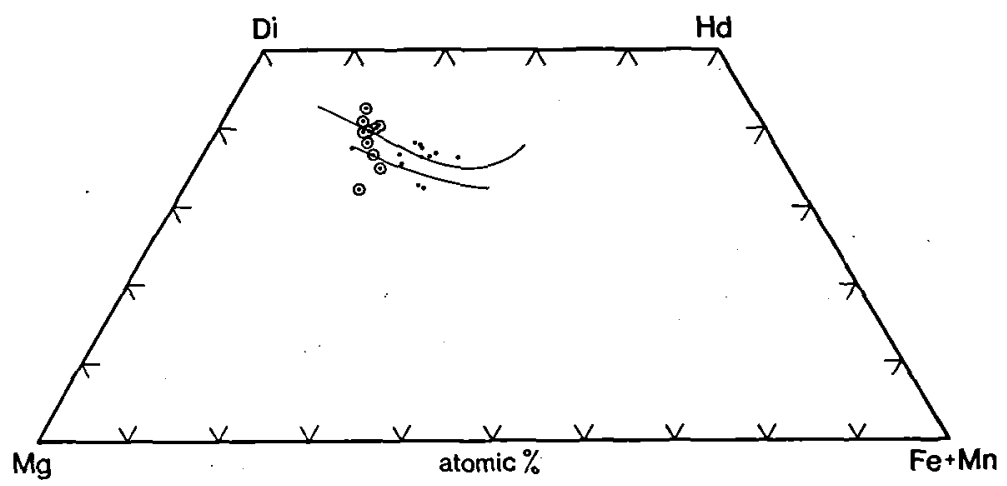

Fig. 4. Augites from near the contact (63016) of the flow from the lower series. Ringed values represent analyses from the central part or large grains. Lines as in fig. 2. 


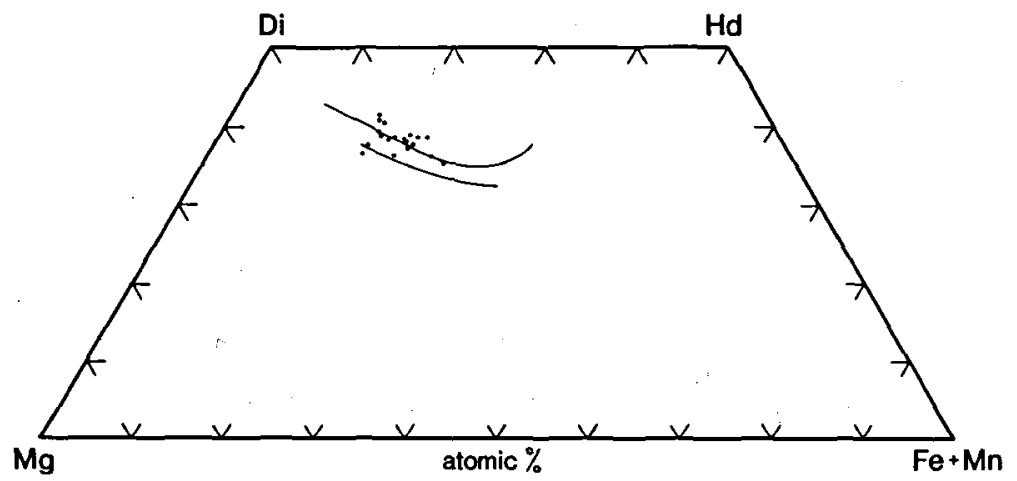

Fig. 5. Augites from the interior of the flow from the lower series (63023). Lines as in fig. 2.

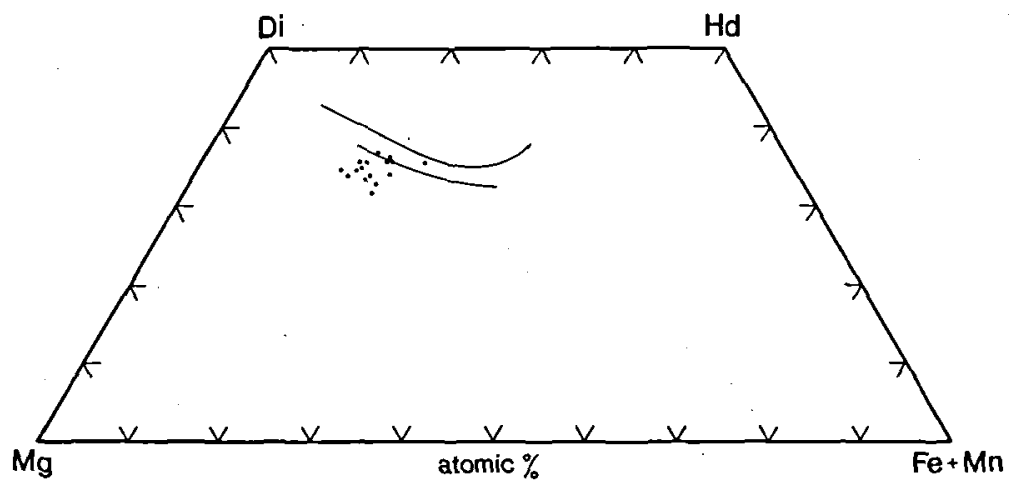

Fig. 6. Augites from the contact sample (63135) of the flow from the middle series. Lines as in fig. 2.

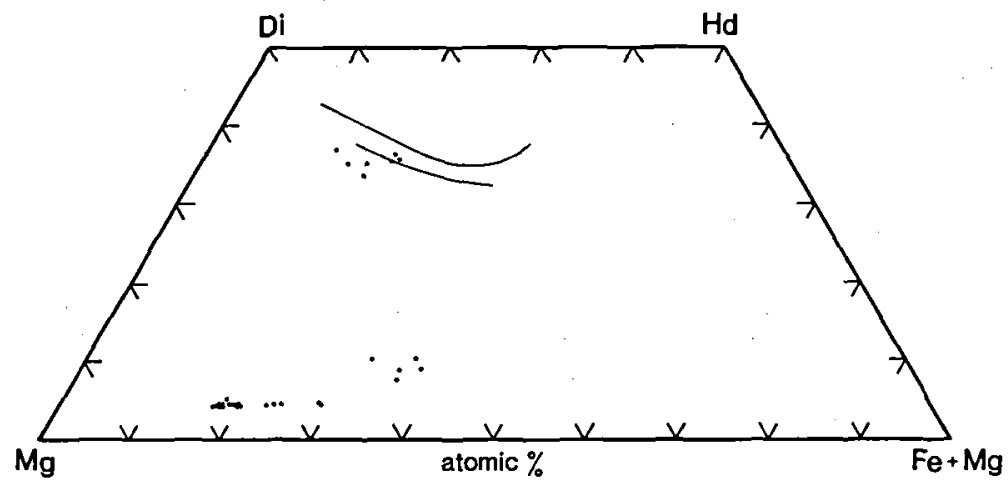

Fig. 7. Bronzites and pigeonites from the flow from the middle series (63135 \& 63141), and augites from the interior of the flow (6314I). Lines as in fig. 2. 


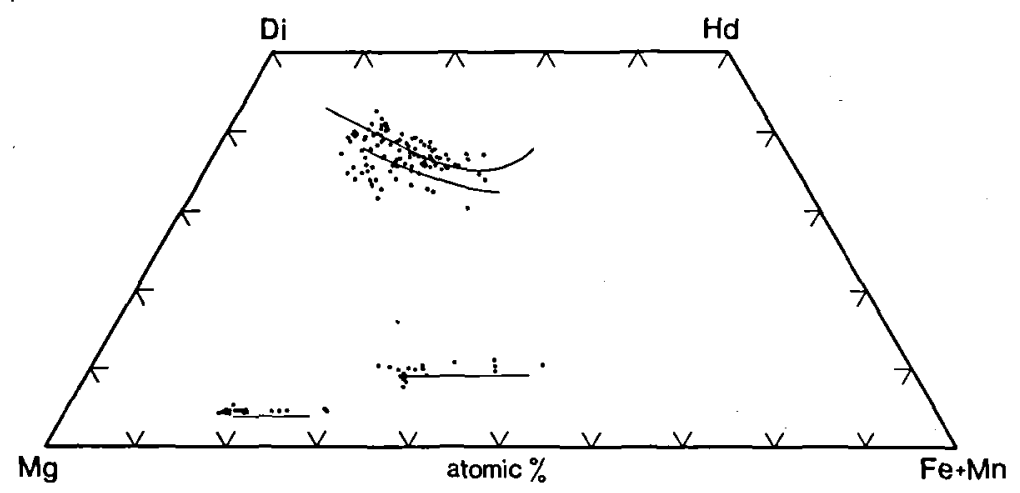

Fig. 8. Total plot of the Faeroese pyroxenes. The upper trend line for augites and the trend lines for Ca-poor pyroxenes are the Skaergaard trends (Brown 1957). The lower trend line for augites is the Thingmuli trend (Carmichael 1967).

flow from the middle series (figs 6 and 7 ) it is the opinion of the author that these are too scattered to show any trend, the larger scattering of the values from the contact sample might however be explained as due to the influence of a quench trend. The position of the plots is remarkable by being rather poor in $\mathrm{Ca}$, lying mainly below the Thingmuli trend. The explanation is probably that the flow as such is rather low in $\mathrm{Ca}$ (table 1).

The bronzites, found only in the flow from the middle series, cover a range from $\mathrm{Ca}_{4.5} \mathrm{Mg}_{78.4} \mathrm{Fe}$ ${ }_{17.1}$ to $\mathrm{Ca}_{4.6} \mathrm{M}_{66.6} \mathrm{Fe}_{28.8}$, and the whole range can be found as zoning within a single grain. The trend of the bronzites is about the same as found for the Skaergaard bronzites (Brown 1957) and the Bushveld bronzites (Atkins 1969), but whereas the Bushveld bronzites deviate from the Skaergaard bronzites in being slightly lower in $\mathrm{Ca}$, the Faeroese bronzites are slightly higher in $\mathrm{Ca}$ than the Skaergaard bronzites.

The five analysed pigeonites from the middle series (fig. 7) range from $\mathrm{Ca}_{10.1} \mathrm{Mg}_{58 \cdot 3} \mathrm{Fe}_{31 \cdot 6}$ to $\mathrm{Ca}_{10 \cdot 1}$ $\mathrm{Mg}_{53.5} \mathrm{Fe}_{36 \cdot 4}$, but between these two end-members the $\mathrm{Ca}$-values reach a minimum of $7.5 \%$.

From the flow from the upper series 14 pigeonite analyses are available, they cover a range from $\mathrm{Ca}_{10.1} \mathrm{Mg}_{57.0} \mathrm{Fe}_{32.9}$ to $\mathrm{Ca}_{10.4} \mathrm{Mg}_{40.1} \mathrm{Fe}_{49.5}$, with Ca-values fluctuating between 8.4 and $11.0 \%$.

The trend is about the same as for the Skaergaard pigeonites (Brown 1957) and the Bushveld pigeonites (Atkins 1969), but as was the case for the bronzites, the pigeonites from the Faeroe Is- lands are slightly higher in $\mathrm{Ca}$, and the Bushveld pigeonites sligtly lower in $\mathrm{Ca}$ than the Skaergaard pigeonites. The amounts of $\mathrm{Ca}$ in the Faeroese pigeonites correspond to the amounts found in the Thingmuli pigeonites (Carmichael 1967) and in the Tasmanian pigeonites from the dolerite at Red Hill (McDougall 1961), but whereas the Ca-contents in as well the Thingmuli pigeonites as the Tasmanian pigeonites increase with fractionation, the Faeroese pigenoites must be characterised as rather steady for higher values of $\mathrm{Fe}$ although they fluctuate for lower values of $\mathrm{Fe}$. Investigations of the Makaopuhi lava lake by Evans \& Moore (1968) have shown that increase in $\mathrm{Ca}$ with $\mathrm{Fe}$-enrichment of pigeonite is connected with chilled rocks, whereas with slower cooling the pigeonite trend is nearly horizontal.

Fig. 8 shows all the Faeroese pyroxenes plotted in the same diagram.

\section{Distribution of minor elements between augites and $\mathrm{Ca}$-poor pyroxenes}

It is generally accepted that augites are enriched in $\mathrm{Al}$ and impoverished in $\mathrm{Mn}$ relative to $\mathrm{Ca}$-poor pyroxenes. As far as $\mathrm{Al}$ is concerned this is also the case with the Faeroese pyroxenes. Concerning $\mathrm{Mn}$, however, it holds true only for augites and pigeonites, whereas $\mathrm{Mn}$ in the bronzites varies from below the corresponding augites in the low fractionation stages (central part of grains) to above 
augites in the highest fractionation stage (rim part of grains).

It is frequently stated that the distribution of $\mathrm{Mn}$ between augites and Ca-poor pyroxenes is a consequence of $\mathrm{Mn}$ following $\mathrm{Fe}^{++}$. In the present investigation there seems to be no correlation between $\mathrm{Mn}$ and $\mathrm{Fe}^{++}$, and it is noteworthy that in the augites of the middle series $\mathrm{Fe} 0$ varies from 7.96 to $14.9 \%$ while $\mathrm{Mn0}$ remains constant at $0.26 \%$.

Also $\mathrm{Na}$ is enriched in augites relative to $\mathrm{Ca}$ poor pyroxenes, as has been found for the Skaergaard pyroxenes (Brown 1957) and the Thingmuli pyroxenes (Carmichael 1967).

Concerning $\mathrm{Ti}$ and $\mathrm{Fe}^{+++}$there are different opinions. Brown (1957) found $\mathrm{Ti}$ and $\mathrm{Fe}^{+++}$enriched in augite, Carmichael (1967) found $T i$ enriched in augite, and Atkins (1969) found Ti, and with a single exception also $\mathrm{Fe}^{+++}$, to be enriched in augite, whereas McDougall (1961) found pigeonite enriched in $\mathrm{Ti}$ and $\mathrm{Fe}^{+++}$relative to augite in the Tasmanian dolerite from Red Hill. In the Faeroese pyroxenes $\mathrm{Ti}$ is clearly enriched in augites relative to Ca-poor pyroxenes. Concerning $\mathrm{Fe}^{+++}$, the values are not analytically determined in the Faeroese pyroxenes, but calculated, and the calculated $\mathrm{Fe}^{+++}$values show large scattering, however, the highest values are obtained for the augites, and the view of Atkins (1969) that $\mathrm{Fe}^{+++}$behave sympathetically with $\mathrm{Fe}^{++}$gets no support from the calculated values of $\mathrm{Fe}^{+++}$from the Faeroese pyroxenes.

\section{Fractionation trends of the minor elements}

\section{$\mathrm{Na}$}

The $\mathrm{Na}_{2} \mathrm{O}$ contents of the augites from the Faeroe Islands basalts vary from 0.21 to $0.38 \%$, which are relatively low values as LeBas (1962) gives the average value of $\mathrm{Na}_{2} \mathrm{O}$ for tholeiitic basalts as $0.35 \%$. With the exception of two analyses $(0.35$ and $0.38 \%$ ) the values from the Faeroe Islands are all below this average. The $\mathrm{Na}_{2} \mathrm{O}$ values, however, correspond to the values found for the Thingmuli augites (Carmichael 1967).

In the flow from the lower series there is no significant variation in the $\mathrm{Na}$ content with fractionation. In the flow from the middle series the highest $\mathrm{Na}$ values are obtained in the middle of the fractionation range represented, that is about $\mathrm{Fe} / \mathrm{Fe}+\mathrm{Mg}+\mathrm{Ca}=20-21 \%$. In the flow from the upper series $\mathrm{Na}$ shows a slight increase with fractionation. $\mathrm{Na}$ is frequently stated as decreasing with fractionation (Brown 1957, Atkins 1969, Walker, Ware \& Lovering 1973), but the increase in $\mathrm{Na}$ found in the flow from the upper series of the Faeroe Islands basalts is in agreement with Le Bas (1962) who states that $\mathrm{Na}$ decreases in augites of the high-alumina series and increases in the tholeiite series.

In the bronzites $\mathrm{Na}$ remains steady, and although the values of table 4 might indicate an increase in $\mathrm{Na}$ of the pigeonite, the author believes that $\mathrm{Na}$ also in the pigeonites remains steady (this belief is based on the evidence from several other analyses of pigeonite, not published because their sum exeeds $101 \%$ ).

The amounts of Na present in the Ca-poor pyroxenes correspond to the amounts of $\mathrm{Na}$ in the Ca-poor pyroxenes from Bushveld and the $\mathrm{Pa}$ lisades Sill. Atkins (1969) found Na steady in the orthopyroxenes and a slight increase in the pigeonites of Bushveld. Walker, Ware \& Lovering (1973) state that there appears to be a tendency to increase for the orthopyroxenes as well as the pigeonites of the Palisades Sill.

\section{Mn}

The values of $\mathrm{Mn} 0$ of the augites from the Faeroe Islands basalts lie in the middle of the range generally reported for $\mathrm{Mn} 0$ in augites. In the flow from the lower series $\mathrm{Mn}$ is fluctuating without any trend. In the flow from the middle series $\mathrm{Mn}$ is remarkably constant throughout the whole fractionation range represented. In the flow from the upper series $\mathrm{Mn}$ is also fluctuating, but shows a slight increase with fractionation.

Mn0 values of the bronzites are rather low compared to the values generally reported for orthopyroxenes, but they correspond to the values of the Bushveld bronzites found by Atkins (1969), and like the Bushveld bronzites the Faeroese bronzites show an increase in $\mathrm{Mn}$ with fractionation.

The pigeonite from the flow from the upper series has $\mathrm{Mn} 0$ values corresponding to the values generally reported for pigeonites, whereas the content of $\mathrm{MnO}$ in the pigeonite from the flow from the middle series is considerably lower. $\mathrm{Mn} 0$ in the pigeonite from the flow from the middle series is similar to the Mn0 content of the bronzite of this 
flow. Besides the analysis of pigeonite given in table 4 this statement is confirmed by several unpublished analyses of pigeonite.

\section{$\mathrm{Al}$ and $\mathrm{Ti}$}

The $\mathrm{Al}_{2} \mathrm{O}_{3}$ values for the augites lie within the range generally reported for augites, whereas the $\mathrm{TiO}_{2}$ values are rather high as LeBas (1962) states that non-alkaline clinopyroxenes commonly have less than $1 \% \mathrm{TiO}_{2}$. However, similar high values of $\mathrm{TiO}_{2}$ are reported from augites from Kap Edvard Holm by Elsdon (1971), and almost as high values of $\mathrm{Ti}_{2}$ are found in the Skaergaard augites (Brown 1957) and the Thingmuli augites (Carmichael 1967).

In the augites from the lower series $\mathrm{Al}_{2} \mathrm{O}_{3}$ as well as $\mathrm{TiO}_{2}$ decreases with fractionation, the augites from the middle series show rather fluctuating values of $\mathrm{Al}_{2} \mathrm{O}_{3}$ and $\mathrm{TiO}_{2}$ but both tend to show a decrease with fractionation. In the upper series no trend can be found for either $\mathrm{Al}_{2} \mathrm{O}_{3}$ or $\mathrm{Ti}_{2}$.

In the bronzites $\mathrm{Al}_{2} \mathrm{O}_{3}$ and $\mathrm{TiO}_{2}$ increase in the earliest fractionation stages, remain steady in the middle fractionation stages, and in the latest fractionation stages $\mathrm{Al}_{2} \mathrm{O}_{3}$ decreases while $\mathrm{TiO}_{2}$ again increases.

The pigeonites from the middle series have about the same amount of $\mathrm{TiO}_{2}$ as the pigeonites from the upper series, whereas they have considerably more $\mathrm{Al}_{2} \mathrm{O}_{3}$, but the same relationship holds true for the corresponding augites.

With the exception of Himmelberg \& Ford (1976) who found no obvious trend for $\mathrm{Al}$ and $\mathrm{Ti}$ in the pyroxenes from the Dufek intrusion, Antarctica, authors generally agree that $\mathrm{Al}_{2} \mathrm{O}_{3}$ decreases with fractionation, whereas the opinions on $\mathrm{TiO}_{2}$ differ. In the Skaergaard $\mathrm{Ti}$ hardly varies (Brown 1957), in the Tasmanian dolerite at Red Hill Ti increases with fractionation (McDougall 1961). LeBas (1962) stated that $\mathrm{Ti}$ rises in augites from non-alkaline as well as alkaline rocks, however, LeBas did not consider augites with $\mathrm{Fe} / \mathrm{Fe}$ $+\mathrm{Mg}+\mathrm{Ca}$ exceeding $18 \%$. Carmichael (1967) found that $\mathrm{Ti}$ tends to decrease in augites from Thingmuli. Atkins (1969) found $\mathrm{Ti}$ to increase in the Bushveld pyroxenes. Walker, Ware \& Lovering (1973) found that $\mathrm{Ti}$ in augites from the $\mathrm{Pa}$ lisades Sill increases until $\mathrm{Fe} / \mathrm{Fe}+\mathrm{Mg}+\mathrm{Ca}$ reaches $35.6 \%$, whereafter $\mathrm{Ti}$ decreases.

In the Faeroese augites $\mathrm{Al}_{2} \mathrm{O}_{3}$ as well as $\mathrm{TiO}_{2}$ decrease in the flows from the lower and middle series, most markedly for the lower series, whereas no trends were found in the flow from the upper series. However, in all three flows it is striking that the variations in $\mathrm{Al}_{2} \mathrm{O}_{3}$ are followed closely by $\mathrm{TiO}_{2}$ in the augites, whereas the correlation between $\mathrm{Al}_{2} \mathrm{O}_{3}$ and $\mathrm{TiO}_{2}$ is considerably weaker or non existent in the bronzites.

A close correlation between $\mathrm{Al}$ and $\mathrm{Ti}$ is to be expected, as it is generally supposed that the substitution of $\mathrm{Al}^{3+}$ for $\mathrm{Si}^{4+}$ in $\mathrm{Z}$-positions is counterbalanced by introduction of $\mathrm{Ti}^{4+}$ in the otherwise mainly divalently occupied M-positions.

The values of the Faeroese pyroxenes clearly follow the equation: $\mathrm{Al}_{\mathrm{Z}}+\mathrm{Fe}_{\mathrm{Z}}^{+*+}=\mathrm{Al}_{\mathrm{M}}+\mathrm{Fe}_{\mathrm{M}}^{++}$ $+2 \mathrm{Ti}_{\mathrm{M}}-\mathrm{Na}$ which must be obeyed in order to maintain balance of charges. (Any Ti which might be present in Z-positions will not influence the charge balance, but $\mathrm{K}$, when determined, should be subtracted on the right side of the equation like $\mathrm{Na}$ ). In the following section the variation relationships between $\mathrm{Ti}$ and $\mathrm{Al}$ as distributed between Z-and M-positions shall be dealt with.

\section{Relationships between $\mathrm{Ti}$ and $\mathrm{Al}$ as distributed between $\mathrm{Z}$ - and M-positions}

In the augites from the lower series $\mathrm{Ti}$, and $\mathrm{Al}_{\mathrm{Z}}$ as well as $\mathrm{Al}_{\mathrm{M}}$ decreases until the disappearence of $\mathrm{Al}_{\mathrm{M}}$, whereafter $\mathrm{Ti}$ and $\mathrm{Al}_{\mathrm{Z}}$ remain steady.

In the augites from the middle series $\mathrm{Ti}$ remains rather steady, but $\mathrm{Al}_{\mathrm{Z}}, \mathrm{Al}_{\mathrm{M}}$ and $\mathrm{Fe}^{+++}$(and to some extent also $\mathrm{Na}$ ) all fluctuate so heavily that it is difficult to observe any pattern in most of the fractionation range. However, in the latest stage $\mathrm{Fe}^{+++}$ disappears and $\mathrm{Al}_{Z}$ decreases markedly, while $\mathrm{Al}_{\mathrm{M}}$ shows a corresponding increase.

In the augites from the upper series there is no obvious trend for $\mathrm{Ti}$ and $\mathrm{Al}_{Z}$, whereas $\mathrm{Al}_{M}$ clearly increases in the later stages of fractionation, but this increase is compensated by a corresponding decrease in $\mathrm{Fe}_{\mathrm{M}}^{+++}$(and to some extent also by the variation in $\mathrm{Na}$ ).

In the bronzites $\mathrm{Ti}$ increases slightly in the earliest fractionation stages while $\mathrm{Al}_{Z}$ and $\mathrm{Al}_{M}$ fluctuate, in the middle fractionation stages $\mathrm{Ti}, \mathrm{Al}_{\mathrm{Z}}$ and $\mathrm{Al}_{\mathrm{M}}$ all remain rather steady, but in the latest fractionation stages $\mathrm{Ti}$ and $\mathrm{Al}_{Z}$ increase, whereas $\mathrm{Al}_{M}$ decreases to zero, the decrease in $\mathrm{Al}_{\mathrm{M}}$ being compensated by increase in $\mathrm{Fe}^{+++}$.

The variations in $\mathrm{Ti}, \mathrm{Al}_{\mathrm{Z}}, \mathrm{Al}_{\mathrm{M}}, \mathrm{Fe}^{+++}$and $\mathrm{Na}$ 
thus obviously are very complicated, but it is a common feature that $\mathrm{Ti}$ generally behave sympathetically with total Al. Exceptions to this rule only occur in cases where a decrease in total $\mathrm{Al}$ is combined with an increase in $\mathrm{Al}_{\mathrm{Z}}$, or an increase in total $\mathrm{Al}$ is combined with a decrease in $\mathrm{Al}_{\mathrm{Z}}$. These combinations are found three times in the eight bronzite analyses, but only once in the 19 augite analyses.

For the Skaergaard pyroxenes Brown (1957). found that $\mathrm{Al}$ in augites as well as in $\mathrm{Ca}$-poor pyroxenes decreases steadily during fractionation, both in $\mathrm{Z}$ - and $\mathrm{M}$-positions, the decrease being more marked for the augites. For the Bushveld pyroxenes Atkins (1969) found that Al as percentage of Z-positions as well as $\mathrm{M}$-positions were greater in the augites than in the coexisting orthopyroxenes, and that the ratio between the pairs were strikingly consistent: the ratio of $\mathrm{Al}_{\mathrm{Z}}$ in augite to $\mathrm{Al}_{Z}$ in orthopyroxene expressed as percentages of $Z$-positions was $1.1-1.2$, and the corresponding ratio for M-positions 2.1 - 5.1. The Alenrichment in the augites thus is most pronounced for M-positions in the Bushveld pyroxenes.

For sample 63135 the ratio for $\mathrm{Al}_{\mathrm{Z}}$ varies from 1.9 to 5.4, and for $\mathrm{Al}_{\mathrm{M}}$ from 0 to 6.3. If only the rim of bronzites is considered to be coexisting with the augite, the range for $\mathrm{Al}_{Z}$ is narrowed to $1.9-$ 3.9, and for $\mathrm{Al}_{\mathrm{M}}$ to 0 - 3.1.

For sample 63141 the ratio for $\mathrm{Al}_{\mathrm{Z}}$ varies from 2.2 to 2.8 , and for $\mathrm{Al}_{\mathrm{M}}$ from 0.5 to $0.4 / 0$. If only the rim of bronzites is considered to be coexistent with augite the value 2.2 is obtained for $\mathrm{Al}_{\mathrm{Z}}$ and $0.4 / 0$ for $\mathrm{Al}_{M}$.

Thus for the Faeroese pyroxenes there is noconsistency of the ratios, but they show clearly that compared to the Bushveld pyroxenes the Faeroese augites are considerably more enriched in $\mathrm{Al}_{Z}$, relative to the bronzites, whereas the augites concerning $\mathrm{Al}_{\mathrm{M}}$ can be as well enriched as impoverished. In this respect the Faeroese pyroxenes compare better with the Skaergaard pyroxenes, as Brown (1957) found that whereas the augite always contains more $\mathrm{Al}$ in the $\mathrm{Z}$-positions than the $\mathrm{Ca}$-poor pyroxene from the same rock, the augite contains about the same or slightly less in the Mpositions.

For 63141 the ratio between augite and pigeonite for $\mathrm{Al}_{\mathrm{Z}}$ is 1.7 and for $\mathrm{Al}_{\mathrm{M}}$ 8.0, compared to pigeonite the augite is thus preferentially enriched in $\mathrm{Al}$ in M-positions.
In 63182 from the flow from the upper series the augite has no $\mathrm{Al}$ in $\mathrm{M}$-positions, this holds true for one of the pigeonite analyses too, whereas the other has a small amount of $\mathrm{Al}$ in $\mathrm{M}$-positions. The ratio for $\mathrm{Al}$ in $\mathrm{Z}$-positions varies from 2.6 to 3.1. Thus, while $\mathrm{Al}$ in $\mathrm{M}$-positions is absent, the enrichment in $\mathrm{Al}$ in Z-positions of the augite compared to pigeonite is considerably more pronounced in the flow from the upper series than in the flow from the middle series.

\section{Determination of magma type based on pyroxene composition after Nisbet \& Pearce (1977)}

Values of the discriminant functions of Nisbet \& Pearce (1977) are given in table 5. In an $F_{1}-F_{2}$ diagram two of three augites from the lower series plot in the field where ocean-floor and volcanic arc basalts overlap, and the third plots in the field where ocean-floor basalts and within-plate tholeiites overlap.

Table 5. Values of discriminant functions calculated after Nisbet \& Pearce (1977)

\begin{tabular}{lcccc} 
& $\begin{array}{c}\text { Sample } \\
\text { number }\end{array}$ & $\begin{array}{c}\text { Analysis } \\
\text { number }\end{array}$ & $F_{\mathbf{1}}$ & $\mathbf{F}_{\mathbf{2}}$ \\
\hline \multirow{4}{*}{ Lower series } & 63016 & 1 & -0.858 & -2.465 \\
& 63016 & 2 & -0.824 & -2.533 \\
& 63016 & 3 & -0.837 & -2.443 \\
\hline & 63135 & 4 & -0.785 & -2.506 \\
& 63135 & 5 & -0.795 & -2.515 \\
Middle series & 63135 & 6 & -0.790 & -2.515 \\
& 63135 & 7 & -0.807 & -2.495 \\
& 63135 & 8 & -0.784 & -2.530 \\
& 63135 & 9 & -0.820 & -2.528 \\
& 63135 & 10 & -0.825 & -2.501 \\
& 63141 & 11 & -0.822 & -2.504 \\
& 63135 & 12 & -0.826 & -2.540 \\
\hline \multirow{6}{*}{ Upper series } & 63182 & 13 & -0.833 & -2.477 \\
& 63176 & 14 & -0.820 & -2.511 \\
& 63182 & 15 & -0.835 & -2.487 \\
& 63176 & 16 & -0.840 & -2.478 \\
& 63176 & 17 & -0.871 & -2.521 \\
& 63176 & 18 & -0.822 & -2.461 \\
& 63176 & 19 & -0.842 & -2.494 \\
\hline
\end{tabular}

Of the nine augites from the middle series four fall in the field where ocean-floor and volcanic arc basalts overlap, three in the field where oceanfloor basalts and within-plate tholeiites overlap, 


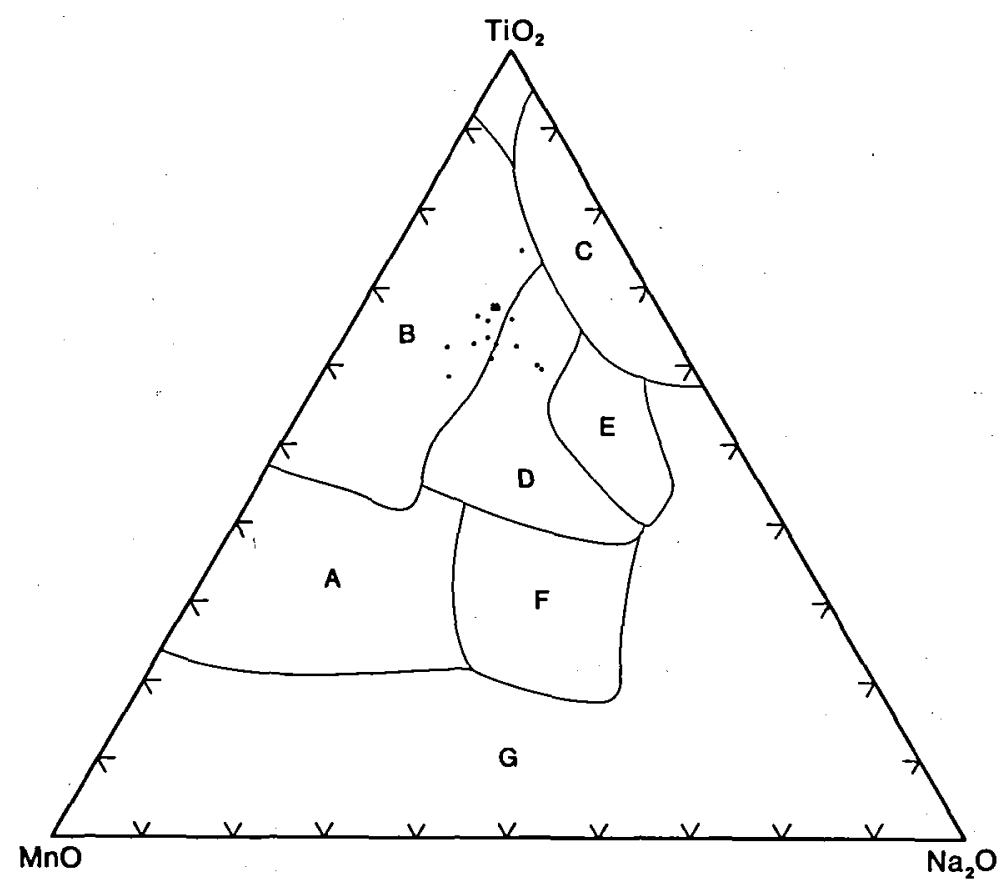

Fig. 9. $\mathrm{TiO}_{2}-\mathrm{MnO}-\mathrm{Na}_{2} \mathrm{O}$ diagram (Nisbet \& Pearce 1977). $\mathrm{A}$ is a field of volcanic arc basalts, $B$ a field of ocean-floor basalts, $C$ and $G$ are fields of within-plate alkali basalts. $F$ is a field where volcanic arc basalts and within-plate alkali basalts overlap, $E$ is a field where volcanic arc basalts, within-plate tholeiites and within-plate alkali basalts overlap, and $D$ is a field where all the basalt types overlap.

and the remaining two on the border between these two fields.

Of the seven augites from the upper series three fall in the field where ocean-floor and volcanic arc basalts overlap, three in the field where ocean-floor basalts and within-plate tholeiites overlap, and the last one on the border between these two fields.

Fig. 9 shows the augites plotted in a $\mathrm{TiO}_{2}-\mathrm{MnO}-$ $\mathrm{Na}_{2} \mathrm{O}$ diagram (Nisbet \& Pearce 1977). Two of the augites from the lower series plot within the field of ocean-floor basalts, the third in the field common to all the basalt types. Six of the nine augites from the middle series plot within the field of ocean-floor basalts, and three in the field common to all basalt types. Five of the seven augites from the upper series plot inside the ocean-floor basalt field, and two on the border between this field and the field common to all basalt types.

In a $\mathrm{SiO}_{2}-\mathrm{TiO}_{2}$ diagram (Nisbet \& Pearce 1977) all the augites will plot inside the ocean-floor ba- salt field, except one which falls just on the borderline.

\section{Summary of conclusions}

Concerning the major elements, $\mathrm{Mg}, \mathrm{Fe}, \mathrm{Ca}$, the Faeroese augites show a quench trend, or at least show a scattering due to quench influence in the contact samples, whereas the augites in the samples from the interior of flows show a more normal trend, comparable to the Skaergaard trend, but the augites from the middle and upper series are generally somewhat lower in $\mathrm{Ca}$.

The trends for bronzites and pigeonites are also comparable to those of the Skaergaard intrusion, but contrary to the augites these Ca-poor pyroxenes are slightly higher in $\mathrm{Ca}$ than the Ca-poor pyroxenes from the Skaergaard intrusion.

The augites are enriched in $\mathrm{Al}, \mathrm{Ti}$ and $\mathrm{Na}$, and 
probably also in $\mathrm{Fe}^{+++}$relative to the Ca-poor pyroxenes of the same rock. Concerning $\mathrm{Mn}$ the augites are impoverished in relation to pigeonites, but hold about the same amount of $\mathrm{Mn}$ as the bronzites.

$\mathrm{Na}$ and Mn remain steady or show a slight increase with fractionation.

The relationships between $\mathrm{Ti}, \mathrm{Al}_{\mathrm{Z}}$ and $\mathrm{Al}_{\mathrm{M}}$ are complicated. They are linked by the equation $\mathrm{Al}_{Z}$ $+\mathrm{Fe}_{\mathrm{Z}}^{+*+}=\mathrm{Al}_{\mathrm{M}}+\mathrm{Fe}_{\mathrm{M}}^{+*+}+2 \mathrm{Ti}_{\mathrm{M}}-\mathrm{Na}$, but the only rather simple trend (decrease in $\mathrm{Ti}, \mathrm{Al}_{\mathrm{Z}}$ and $\mathrm{Al}_{\mathrm{M}}$ until the disappearance of $\mathrm{Al}_{\mathrm{M}}$, whereafter $\mathrm{Ti}$ and $\mathrm{Al}_{\mathrm{Z}}$ remain steady) is obtained for the augites from the lower series, and the simple relationships might very well be due to the fact that only three analyses are available. No matter how complicated the relations between $\mathrm{Ti}, \mathrm{Al}_{\mathrm{Z}}, \mathrm{Al}_{\mathrm{M}}, \mathrm{Fe}^{+++}$ and $\mathrm{Na}$ are, it appears that $\mathrm{Al}_{2} \mathrm{O}_{3}$ and $\mathrm{TiO}_{2}$ behave sympathetically, except when a decrease in total $\mathrm{Al}$ is combined with an increase in $\mathrm{Al}_{\mathrm{Z}}$, or an increase in total $\mathrm{Al}$ is combined with a decrease in $\mathrm{Al}_{\mathrm{Z}}$. These combinations are relatively frequent in the bronzites, but seldom in the augites.

The evidence on magma type from the pyroxene compositions consistently shows oceanic affinities, whereas the evidence from whole rock analyses shows oceanic affinities in a $\mathrm{TiO}_{2}-\mathrm{K}_{2} 0-\mathrm{P}_{2} \mathrm{O}_{5}$ diagram, but plots in the field of within-plate basalts or the field of volcanic arc basalts in a $F_{1}-F_{2}$ diagram.

Acknowledgement. Thanks are due to the Danish Natural Science Research Council for providing the electron microprobe facilities.

\section{Dansk sammendrag}

Pyroxenerne fra en lavabænk fra hver af de tre lavaserier på Færøerne er blevet analyseret med mikrosonde. Lavabænken fra den nedre serie har augit som eneste pyroxen. Bænken fra mellemste serie har bronzit som strokorn og augit og pigeonit $i$ grundmassen. Bænken fra ovre serie har augit og pigeonit, pigeonit findes dog ikke ved kontakten, men dukker op et par meter fra kontakten og tiltager indefter $\mathrm{i}$ bænken.

Bjergartsanalyser af de undersøgte prøver er vist i tabel $1, \mathrm{og}$ analyser af pyroxenerne er vist i tabel 3 og 4 . Foruden de 30 analyser $i$ tabellerne er resultaterne fra 116 partielle pyroxen-analyser, omfattende $\mathrm{Mg}, \mathrm{Fe}$ og $\mathrm{Ca}$, benyttet i diagrammerne fig. 2-8. Udviklingen i pyroxenerne svarer stort set til den der kendes fra Skærgårdsintrusionen i Østgrønland, men augiterne i mellemste og øvre serie fra Færøerne er fattigere pá calcium, og bronziterne og pigeoniterne er lidt rigere pá calcium end de tilsvarende pyroxener fra Skærgárdsintrusionen. Endvidere er udviklingen af augiterne fra kontaktprøverne tydeligt prægede af den hurtige afkbling.
Augiterne er rigere pả $\mathrm{Al}$, Ti og $\mathrm{Na}$ end bronziter og pigeoniter fra samme prove. Augiterne er fattigere på Mn end pigeoniterne, men har omtrent samme indhold af Mn som bronziterne.

Indholdet af $\mathrm{Mn}$ og $\mathrm{Na}$ er ret konstant eller viser en svag stigning med stigende jernindhold. Variationerne i Al og Ti med stigende jernindhold er ret komplicerede, men det er tydeligt at disse to grundstoffer følges ad i udpræget grad i augiterne, men væsentlig mindre udpræget $\mathrm{i}$ bronziterne.

$F_{1}-F_{2}$ værdierne (Nisbet \& Pearce 1977) svarer dels til det felt, hvor oceanbundsbasalter og pladetholeiter overlapper hinanden, og dels til det felt, hvor oceanbundsbasalter og basalter fra vulkanbuer overlapper hinanden. I et $\mathrm{TiO}_{2}-\mathrm{Mn} 0-\mathrm{Na}_{2} \mathrm{O}$ diagram (Nisbet $\&$ Pearce 1977) falder Færø-pyroxenerne overvejende i feltet for oceanbundsbasalter, men nogle falder i det felt, der er fælles for alle basalt typerne.

\section{References}

Atkins, F.B. 1969: Pyroxenes of the Bushveld intrusion, South Africa. J. Petrology 10: 222-249.

Bollingberg, H., Brooks, C.K. \& Noe-Nygaard, A. 1975: Trace element variations in Faeroese basalts and their possible relationships to ocean floor spreading history. Bull. geol. Soc. Denmark 24: 55-60.

Brooks, C.K. \& Jakobsson, S.P. 1974: Petrochemistry of the volcanic rocks of the North Atlantic ridge system. In Kristjansson, L. (editor): Geodynamics of Iceland and the North Atlantic Area 139-154, (N.A.T.O. Advanced Study Institute Series) Reidel: Dordrecht.

Brown, G.M. 1957: Pyroxenes from the early and middle stages of fractionation of the Skaergaard intrusion, East Greenland. Mineralog. Mag. 31: 511 -543.

Carmichael, I.S.E. 1967: The mineralogy of Thingmuli, a Tertiary volcano in eastern Iceland. Am. Miner. 52: 1815-1841.

Coombs, D.S. 1963: Trends and affinities of basaltic magmas and pyroxenes as illustrated on the diopside-olivine-silica diagram. Min. Soc. Am. Special Paper 1: 227-250.

Elsdon, R. 1971: Clinopyroxenes from the Upper Layered Series Kap Edvard Holm, East Greenland. Mineralog. Mag. 38: 49-57.

Evans, B.W. \& Moore, J.G. 1968: Mineralogy as a function of depth in the prehistoric Makaopuhi tholeiitic lava lake, Hawaii. Contrib. Mineral. Petrol. 17: 85-115.

Finger, L.W. 1972: The uncertainty in the calculated ferric iron content of a microprobe analysis. Carnegie Inst. Wash. Yearb. 71:600-603.

Hess, H.H. 1949: Chemical composition and optical properties of common clinopyroxenes, Part 1. Am. Miner. 34: 621666 .

Himmelberg, G.R. \& Ford, A.B. 1976: Pyroxenes of the Dufek intrusion, Antarctica. J. Petrology 17: 219-243.

LeBas, M.J. 1962: The role of aluminum in igneous clinopyroxenes with relation to their parentage. Am. Jour. Sci. 260: 267-288.

Manson, V. 1967: Geochemistry of basaltic rocks: major elements. In Hess, H.H. \& Poldervaart, A. (editors): Basalts 1: 215-269. Interscience: New York.

McDougall, I. 1961: Optical and chemical studies of pyroxenes in a differentiated Tasmanian dolerite. Am. Miner. 46: 661687.

Nisbet, E.G. \& Pearce, J.A. 1977: Clinopyroxene composition in mafic lavas from different tectonic settings. Contrib. Mineral. Petrol. 63: 149-160.

Noe-Nygaard, A. 1962: The geology of the Faeroes. Quart. $J$. geol. Soc. Lond. 118: 375-383.

Noe-Nygaard, A. 1966: Chemical composition of tholeitic basalts from the Wyville-Thompson ridge belt. Nature 212: 272-273. 
Noe-Nygaard, A. \& Rasmussen, J. 1968: Petrology of a 3000 metre sequence of basaltic lavas in the Faeroe Islands. $L i$ thos 1: 286-304.

Pearce, J.A. 1976: Statistical analysis of major element patterns in basalts. J. Petrology 17: 15-43.

Pearce, T.H., Gorman, B.E. \& Birkett, T.C. 1975: The Ti0 ${ }_{2}-\mathrm{K}_{2} \mathrm{O}-$ $\mathrm{P}_{2} \mathrm{O}_{5}$ diagram: a method of discriminating between oceanic and non-oceanic basalts. Earth Planet. Sci. Lett. 24: 419426.

Rasmussen, J. \& Noe-Nygaard, A. 1969: Beskrivelse til Geologisk Kort over Færøerne. Danmarks geol. Unders. (1), 24, $370 \mathrm{pp}$. (English edition: Geology of the Faeroe Islands. Danmarks geol. Unders. (1), 25: 142 pp.).

Schilling, J.-G. \& Noe-Nygaard, A. 1974: Faeroe-Iceland plume: rare-earth evidence. Earth Planet. Sci. Lett. 24: 1-14.

Smith, D. \& Lindsley, D.H. 1971: Stable and metastable augite crystallization trends in a single basalt flow. Am. Miner. 56: 225-233.

Springer, G. 1967: Die Berechnung von Korrekturen für die quantitative Elektronenstrahl-Mikroanalyse. Fortschr. Mineral. 45: 103-124.

Sweatman, T.R. \& Long, J.V.P. 1969: Quantitative electronprobe microanalysis of rock-forming minerals. J. Petrology 10: 332-379.

Walker, K.R., Ware, N.G. \& Lovering, J.F. 1973: Compositional variations in the pyroxenes of the differentiated Palisades Sill, New Jersey. Bull. geol. Soc. Amer. 84: 89-110.

Watkins, N.D. \& Haggerty, S.E. 1967: Primary oxidation variation and petrogenesis in a single lava. Contrib. Mineral. Petrol. 15: 251-271.

Yoder, H.S. \& Tilley, C.E. 1962: Origin of basalt magmas. $J$. Petrology 3: 342-532. 